\title{
Preschool and early school education of migrants and minorities in Poland. Teachers' competences in the light of regulations and practice
}

\author{
Justyna Wojniak $^{1 \mathrm{a}}$, Kinga Orzeł-Dereń ${ }^{1}$ \\ ${ }^{1}$ Pedagogical University of Krakow, ul. Podchorążych 2, 30-084 Krakow, Poland
}

\begin{abstract}
According to Polish Constitution all children, regardless of their nationality and legal status, have the right to education, and the obligation to study up to the age of 18 [1]. So far there have been no comprehensive solutions to support kindergartens and schools, as well as teachers and educators who are not prepared to work with children of different cultures, especially children with little or no knowledge of Polish language. Although Poland is still a relatively homogeneous from the ethnic and religious point of view, and ethnic minorities account for 2.5$3 \%$ (about 1-1.2 million) of the population, number of foreigners living in Poland makes their education an increasing challenge. The paper is divided into two sections. The first one is an overview of the EU regulations as well as national legal provisions concerning education of children of the migrant background. The second part discusses challenges and tasks indicated by teachers who work with students of foreign origin. They involve not only adjusting the teaching content to intercultural requirements, but also, more broadly, adaptation of working methods to specific needs of various participators of educational process. Work in such circumstances forces teachers and school management to seek new solutions and, above all, to acquire or develop new, intercultural competences.
\end{abstract}

Keywords: migrants, minorities, perception, early school education

\section{Introduction}

An increasing number of migrant pupils in European schools has implications for education systems. In the first instance, schools must be adjusted to their presence and take into consideration their particular needs, from the point of view of an equal right to education

${ }^{a}$ Corresponding author: jwojniak@up.krakow.pl 
and its high quality. These conditions are vital for effective education, which is able to provide these pupils with instruments necessary to become integrated, successful and productive citizens of the host country.

\section{Migrant and Minority Education in the European Union Law}

According to the Green Paper by the Commission of the European Communities on Migration \& Mobility, describing challenges and opportunities for EU education systems, a broad concept of the term "migration" should be adopted. Taking it into account, the terms "children from a migrant background", "children of migrants" and "migrant pupils" refer to "the children of all persons living in an EU country where they were not born, irrespective of whether they are third country nationals, citizens of another EU Member State or subsequently became nationals of the host Member State" [2]. The reason of such an attitude is that the specific educational issues might be applied to a significant number of individuals. Moreover, the data that exemplify these issues do not distinguish between the countries of origin, whether their citizens come from the EU member states or from the third countries [3].

In this context one must remember that these are Member States that are responsible for establishing general educational aims and policies. Nevertheless, the challenges of migrants' integration and education are common. An analysis of implementation of the Education and Training 2010 Work Programme proves an existing educational disadvantage of many migrant pupils. It particularly concerns the need of reducing the gaps in educational attainment between migrant pupils and other host peers as well as in the performance and scoring in such areas as science, mathematics and reading [4].

The European Union has already undertaken several different types of activities which impact, directly or indirectly, Member States' policies regarding these issues. The actions related to the issue comprise of: National Contact Points, the European Fund for the Integration of Third-country Nationals, aimed at facilitating integration measures for migrant youth and children. In addition, the Recommendation of the European Parliament and the Council on "Key Competences for Lifelong Learning" of 2006 lists the attitudes, knowledge and skills necessary to facilitate personal fulfilment and development, active citizenship, social inclusion and employment in modern Europe. Such competences as Social and Civic Competences and Cultural Awareness are particularly relevant for developing national educational approaches [5].

One of the most important instruments in this field is Directive 77/486/EEC on the education of the children of migrant workers. According to the Directive's provisions, "Member States shall ensure that free tuition to facilitate initial reception is offered in their territory [to the children of migrant workers], including, in particular, the teaching of the official language or one of the official languages of the host State", and "Member States shall in cooperation with the States of origin, take appropriate measures to promote in coordination with normal education, teaching of the mother tongue and culture of the country of origin" [6]. The impact of the Directive however is limited, as it allows some flexibility in the way these aims are achieved, and the Member States have all developed their own approaches to the teaching migrant children.

The issue of educating the children of migrants has also been addressed by the European Parliament in the Resolution of 2009. The Parliament, among others, "Calls on the Member State governments to ensure education for the children of legal migrants, including the teaching of the official languages of the host country and the promotion of their native languages and cultures" [7]. This institution also believes that preserving and promoting multilingualism must be a part of every school's curriculum, and language-learning should be encouraged from pre-school age to promote inclusion of migrants. The place given to 
teaching in the mother tongue within the curriculum and the organisation of this process must be however left to the Member States [8].

Projects related to intercultural education, school integration of migrant pupils and social inclusion for disadvantaged youth are supported in the framework of the Erasmus+ Programme (2014-2020), while Cohesion Policy, via the Structural Funds - in particular the European Social Fund - support social inclusion projects and measures at national and regional level.

\section{Migrant and Minority Education in Polish Education System}

In Poland, challenges and dilemmas concerning education of the children of migrants remain limited, as the country - from the national and cultural point of view - is a distinctively homogenous one. The groups of various cultural and national backgrounds are as follows:

1. National minorities: Belarusians, Czechs, Lithuanians, Armenians, Russians, Germans, Ukrainians, Jews, Slovaks;

2. Ethnic minorities: Roma, Lemkos, Tatars, Karais;

3. Children of migrants and refugees with different statuses of residence, i.e. tolerated stay, temporary protection, subsidiary protection;

4. Children of repatriates.

In 1990s, there were almost no students of migrant background in Polish schools. The problem began to grow with an increasing number of people applying for a refugee status. Since 2000, intensified immigration of Chechen refugees to Poland has been observed. This situation forced development of new systemic and legal solutions.

An institutional and legal framework for the education of children of migrants in the Polish system is established by the Act on the Education System [9], and the Regulation on Admission of non-Polish citizens to public kindergartens, schools, teacher education establishments and institutions and organizations of additional Polish language learning, additional compensatory activities and learning the language and culture of the country of origin [10]. In case of students with undetermined legal status, the right to education derives from the Constitution of the Republic of Poland of 1997, guaranteeing everyone the right to education, and from international commitments, including above all the provisions of the Convention on the Rights of the Child [11].

What is noteworthy, an amendment of the Act on the Education System of 2009 states that persons who are subject to compulsory education but are not Polish citizens and do not speak Polish or their level of speaking is insufficient to learn, have the right for an additional, free course of Polish, organized by a school authority, namely a commune, which is the smallest administrative district in Poland. The Act on the education system also includes provisions on organizing additional compensatory activities of individual teaching subjects, which are organized by the school authority as well, lasting no longer than 12 months. Non-Polish nationals subject to compulsory education who do not speak Polish at all or speak it at an insufficient level, have the right to be assisted by a person who speaks the language of their country of origin. Such a person is employed as a teacher's assistant by a school principal and this sort of support is also granted for maximum 12 months [12].

Polish legal acts concerning the education system are also addressed to national and ethnic minorities, as well as to the communities using the regional language [13]. These provisions are more detailed than those devoted to the pupils of migrant background. The reason of such an attitude are different educational aims of the mentioned groups. In case of migrant children, the goal is to provide them with the most effective instruments of assimilation and inclusion. Therefore, preserving the language and culture of origin becomes mostly the matter of parents and family members. Moreover, migrant groups in 
Poland, as it was mentioned, are not numerous and usually dispersed - those who live in the refugee centres usually also represent different nationalities. Under such circumstances, opening courses of the language of origin or suitable cultural activities might be complicated from the organisational and financial point of view. On the contrary, in case of national and ethnic minorities in Poland, the aim is to preserve the linguistic and cultural diversity, as well as to sustain their sense of distinct identity.

The European Commission pursues an active policy to protect and support regional and minority languages in Europe. This is the main instrument of promoting multilingualism in the united Europe, based on the provisions of the Charter of Fundamental Rights of the European Union, which states that the Union respects cultural, religious and linguistic diversity [14]. The European Parliament, in its resolution of 2009 on multilingualism, stresses the importance of the languages of national and ethnic minorities used in Europe [15]. This issue was also undertaken by the European Charter for Regional or Minority Languages of 2003, which was signed and adopted by the Republic of Poland.

Effective implementation of these rights depends on diverse legal solutions, taking into account special educational needs manifested by the minority pupils. The Constitution of the Republic of Poland is the basic law regulating the sphere of rights and freedoms of national and ethnic minorities in Poland. Constitutional principles are supplemented by the Act of 2005 on national and ethnic minorities and the regional language.

Other executive acts relating to organization of the education system for children of national and ethnic minorities and those who use a regional language are: 1) Regulation of the Minister of National Education of 2009 on the admission of pre-school education programs and curricula in schools and for the use of school textbooks (in the development and use of textbooks for children and young people of national and ethnic minority groups and using regional languages); 2) Regulation of the Minister of National Education of 2007 on the conditions and manner of assessing, classifying and promoting pupils and students, and carrying out examinations of children and youth from national and ethnic minorities and using regional languages; 3) Regulation of the Minister of National Education of 2001 on requirements for the performance of examinations of children and adolescents from national and ethnic minorities and using regional languages.

This education primarily includes the ability to maintain the sense of identity. At the request of parents, this can be accomplished in separate groups, units or schools, or in groups, units or schools with additional language, history and culture classes. In this case, the inter-departmental group, composed of students of different units, must comprise of at least 7 students in elementary and lower secondary school, and 14 students in upper secondary school. Taking into account organization of the teaching process in combined classes, there should be at least 3 but not more than 14 students. Inter-school teaching groups are also applicable [16].

From the legal and practical point of view, recognition and meeting of educational rights of migrants and minorities in Poland might be also considered on the basis of special educational needs. International origins of this term may be found in the UNESCO Salamanca Statement and Framework for Action on Special Needs Education of 1994. According to its provisions, "Every child has unique characteristics, interests, abilities and learning needs; Education systems should be designed and educational programmes implemented to take into account the wide diversity of these characteristics and needs" [17].

In Polish education system, identification and satisfaction of the individual developmental and educational needs of a pupil, as well as their individual psychophysical abilities form a prerequisite for providing them with psychological and pedagogical assistance [18]. Among the origins of special educational needs, Polish Ministry of National Education indicates: disability, social maladjustment, special aptitudes, specific learning difficulties, disorder of linguistic communication, chronic disease, crisis or 
traumatic situation, adaptive difficulties related to cultural differences or changes in the educational environment resulting, for example, from earlier learning abroad. The last category may be perceived as a useful instrument of effective fulfillment of the needs of children with migrant backgrounds.

Overcoming learning difficulties that result from varied conditions, and adjusting the learning environment to individual developmental characteristics and capabilities of the group of students in question may concern the objectives, content, or methods used in the education process, as well as the organizational forms or teaching resources. These requirements could be hardly met without a wide range of assistance provided to the teachers by the psychological and pedagogical counselling centres. Professionals, who are employed in such institutions, recognize individual developmental and educational needs and psychophysical capabilities of children and adolescents. Another area of support for teachers is the planning and implementation of education and career counseling along with the development of student's interests and talents. Psychological and pedagogical counselling cooperates also with kindergartens, schools and institutions in provision and organization of psychological and pedagogical assistance, development and implementation of individual educational and therapeutic programs as well as individual programs of revalidation and education [19].

The main limitation of this solution is that in the first instance it is addressed to disabled or socially maladjusted pupils. Children from migrant backgrounds demand a more complex and more flexible attitude, depending on their individual situation. One of the instruments used in work with the migrant children is support of the cultural aide. Provisions of the Act on the education system enable to employ a person who speaks the language of the student's country of origin, and Polish schools have the opportunity to finance their employment from public funds. However, the cultural aides are employed on average in the framework of the school project implemented by non-governmental organizations. This situation often results in the lack of interest from the school authorities, namely the communes. The education subsidy received from the state budget is insufficient, and they must provide the financing from their own budget.

The competencies and responsibilities of such a professional are rather the matter of everyday practice than detailed legal regulations [20]. A cultural aide should demonstrate knowledge of Polish and the language spoken by the students under their care. Moreover, the ability to establish a fine contact with the child and the competence in interpersonal communication, ability to deal with difficult situations, knowledge of the culture of the pupils' country of origin, including cultural differences between Polish culture and the culture of origin are regarded as essential [21]. Scope of duties of a cultural aide is also based on expectations of class teachers, school principals and other teachers. Generally, it should include cooperation with teachers, parents and direct assistance to the child [22]

\section{Interculturalism in Polish School}

In many cases, especially taking into consideration the increasing number of migrants, such solutions may turn out to be insufficient. For this reason, one of the most important diversity support strategy within the school environment is building the professional capacity of the teaching staff. The teachers' role is to effectively influence students through the art of social communication. The teacher (...) should shape in their pupils the sense of value and openness to the emerging "otherness" [23].

For this reason, teachers should continually improve their qualifications including intercultural competences. They should pay particular attention to:

1. Basic knowledge concerning the psychological situation of the migrant child and its family, including the consequences of being refugee and migrant; 
2. Skills to understand the consequences of using stereotypes, anti-bias and discrimination skills; skills of the equal treatment of all pupils, while tactfully supporting those children who need to be included in education process;

3. Knowledge of cultural differences, and the manner they affect the pupil's behaviour; understanding the behaviour of a pupil, which may result not only from their individual characteristics, but also from the culture of the country of origin;

4. Reliable cultural knowledge about the origins of pupils, including the most important traditions and customs, the most important holidays, cultural taboos, ways of behaving - for example, respecting specificity of education in the country of origin, roles of women, men and children;

5. Knowledge of existing legislation concerning various groups, such as refugees, migrants ethnic and national minorities, their rights and obligations, count of these groups;

6. Basic knowledge of acculturation, including: adaptation strategies, cultural stress, culture shock, cultural adaptation, intercultural communication challenges - verbal and nonverbal;

7. Ability to adapt materials to the needs and capabilities of migrant children, including the use of individualized methods [24].

The expected model is integration intended to build a common society rather than separate particular groups and marginalize them. However, it must be emphasized that it should be based on the multiculturalism concept, not on simple assimilation. Hence, teachers are expected to be competent in four key areas:

1. Intercultural knowledge;

2. Sensitivity and openness to others and cultural differences (ability of modeling specific situations of responding to cultural differences, creating intergenerational relations standards and building trust and sincere relations with parents);

3. Appropriate attitudes and behaviours resulting from the teacher's familiarization with theirpupils' cultural differences;

4.Language competence and linguistic skills necessary for effective communication with the children of minority or migrant background [25].

As the research proves, the teachers' attitude towards migrant pupils, described by themselves demonstrates ambivalence. On one hand, they declare fear and sense of insecurity, on the other - enthusiasm and willingness to work with foreign students. These attitudes are accompanied by lack of orientation in the specificity of the problems that teachers are supposed to face. As for their competencies, they estimate their level as very low, declaring lack of knowledge and skills, and inadequate preparation for this sort of assignments. When asked to describe their competencies in a more detailed way, the teachers point out a low level of knowledge on cultural diversity and experiences of the migrant children; they also mention insufficient knowledge of foreign languages, lack of knowledge on the problems of the migrants and refugees and rather poor skills in cooperation with parents of different cultural background. Teachers also stress the lack of knowledge on regulations concerning education of the foreign pupils, as well as insufficient preparation for work with culturally heterogeneous group [26].

Other research (carried out by the authors) confirms the pointed data. The research was performed in 2017 in urban primary schools that educate children of refugees, migrants and minorities children. The selection of research area was based on the urban character of the phenomenon of intercultural migration and on occurrence of high cultural diversity in these schools. Women predominated in the study group. The study was carried out in 50 schools. However, the sex parity was changing noticeably as they moved in the hierarchy: almost every fifth manager and every eighth teacher was a man. Long-term work experience was dominant in a group of teachers. 
In the group of school educators there was a greater variation in length of service. When it comes to principals, most of them have short-term work experience. Questionnaires included among others questions related to the issues such as the problems and the need of children of minorities in the institution, the problems and needs connected with working with these students, the concerns of working with parents of these children, the opportunities and needs and resulting from working with these children, assessment of own competencies and skills in working with these children, training needs.

In the researched schools, there were 58 students in total (foreigners, children of minorities), 28 girls and 32 boys. In most schools, there were individual pupils or small groups of them (up to 6). Both the principals and the teachers describe presence of a foreign or a minority child at school as a challenge. The principals showed a friendlier attitude towards the presence of foreign children or migrants children at school than teachers. Teachers described presence of those children more as problem than an opportunity.

Respondents stressed the need to develop solutions to compensate program differences (in relation to migrants children). Cognitive values were pointed most often as a positive aspect of the presence of foreign children and migrant children. The most frequently reported negative impact of the presence of immigrant children and minority children was the unfavorable influence of these children on interpersonal relationships within the group. The most common social problems arising from attendance of migrants and minorities children were conflicts based on cultural differences, racist behavior, xenophobic behavior, intolerant behavior and exclusion of these children. The most important needs of multicultural education teachers were integration of children, adapting the work to specifics of the foreign and migrants children, the need to improve intercultural competences. Teachers also point to the need to contact a psychologist in the context of working in multicultural environment. A large majority of respondents emphasized lack of support from school and of other forms of aid. Most teachers indicated that there should be more classes of Polish for foreign students. The study clearly shows the need and teachers' willingness to participate in trainings and workshops on multicultural issues. The majority of the respondents do not know the specifics and characteristics of work in a multicultural environment. Nearly half of the respondents are unaware of the specificities of working in such an environment, and they are not aware of the needs of culturally diverse children. Teachers perceive differences in the behavior of migrant and minority children, take actions aimed at integrating such children with the group, but they do not feel that they have sufficient competences, which makes working in the multicultural environment stressful for them.

The guidance counsellors seem to be most inadequately prepared for work with migrant pupils - due to the specificity of their professional tasks, their everyday contact with the students is limited, they are concentrated on the formal aspects of their work, and they have only occasional contact with the parents. Another problem mentioned is lack of knowledge on migration processes, the problems and challenges that occur in the broad societal context. Last but not least - limited opportunities of professional development in this field. It is partly caused by the ad hoc actions and temporary projects used as the most popular tool for preparing a teacher to work with children from a migrant background. The latter problem is accompanied by the lack of effective supervision and certification of the competences acquired [27].

\section{Conclusion}

These attitudes and beliefs confirm that development of suitable teacher training programs is a vital condition for effective education of migrants, which results in their further integration and consistency of the entire society. Although every initiative in the field of professional teacher preparation for work with foreigners might be useful, one-day or short 
courses on diversity or non-discrimination issues are not a sufficient measure. Similarly to temporary projects, they do not lead to significant improvement of the teachers' performance. Poland has 5 public and 8 non-public higher education institutions dedicated to educating future teachers. Besides, there are a number of academic and non-academic institutions offering bachelor and master degrees in education. An analysis of their education proves that none of them provide programs or courses devoted to preparing to work in a culturally diverse environment. There are few institutions dedicated to special educational needs, as they are rather focused on work with disabled or socially maladjusted students, thus the gap existing in the Polish teacher education.

The most probable explanation for this situation is obviously a limited need of such initiatives due to Polish demographical specificity. However, it should be kept in mind that in the era of globalization and freedom of movement within EU, the social and educational institutions must be comprehensively prepared for the inflow of migrants and refugees, particularly taking into account the current political and economic crises. For these reasons the point of view expressed by the European Policy Network on the education of children and young people with a migrant background (SIRIUS) should be perceived as the most adequate. According to the SIRIUS report, "Teacher training programs that take diversity as a starting point and integrate the topic into the curricula of all courses - and address it from all perspectives - prepare teachers to become experts in the topic, capable of helping students from migrant backgrounds to achieve their full potential" [28], in favour of the host society as a whole.

\section{References}

1. Konstytucja Rzeczypospolitej Polskiej z dnia 2 kwietnia 1997 r., Dz.U. 1997 nr 78, poz. 483

2. Commission of the European Communities (2008), Green Paper. Migration \& mobility: challenges and opportunities for EU education systems, Brussels, 2, retrieved: http://eur-lex.europa.eu/LexUriServ/LexUriServ.do?uri=COM:2008:0423:FIN:EN:PDF . (Accessed: 2.05.2017)

3. Ibid.

4. EU Council and the Commission, 2010 joint progress report of the Council and the Commission on the implementation of the 'Education and Training 2010 work programme', Official Journal of the European Union 2010/C 117/1 (2010)

5. European Parliament and the Council, Recommendation of 18 December 2006 on key competences for lifelong learning (2006/962/EC), Official Journal of the European Union L 394/10, 30.12.2006, (2006)

6. Council Directive 77/486/EEC of 25 July 1977 on the education of the children of migrant workers, Official Journal L 199, 6.8.1977, (1977)

7. European Parliament, EP resolution of 2 April 2009 on educating the children of migrants, Official Journal of the European Union C 137 E/1, 27.5.2010 (2009a)

8. Ibid.

9. Ustawa z dnia 7 września 1991 r. o systemie oświaty, Dz.U. 1991 nr 95 poz. 425

10. Rozporządzenie Ministra Edukacji Narodowej z dnia 1 kwietnia 2010 r. w sprawie przyjmowania osób niebędących obywatelami polskimi do publicznych przedszkoli, szkół, zakładów kształcenia nauczycieli i placówek oraz organizacji dodatkowej nauki języka polskiego, dodatkowych zajęć wyrównawczych oraz nauki języka i kultury kraju pochodzenia, Dz.U. 2010 nr 57 poz. 361 (1991)

11. UN General Assembly resolution 44/25 of 20 November 1989, Convention on the Rights of the Child, retrieved:

http://www.ohchr.org/Documents/ProfessionalInterest/crc.pdf (Accessed: 5.05.2017)

12. Ustawa z dnia 7 września 1991 r. o systemie oświaty, Dz.U. 1991 nr 95 poz. 425 (1991) 
13. Ustawa z dnia 6 stycznia 2005 r. o mniejszościach narodowych i etnicznych oraz o języku regionalnym, Dz.U. 2005 nr 17 poz. 141 (2005)

14. European Union, Charter of Fundamental Rights of the European Union, Official Journal of the European Communities C 364/1, 18.12.2000 (2000)

15. European Parliament, EP resolution of 24 March 2009 on Multilingualism: an asset for Europe and a shared commitment, Session document A6-0092/2009, 24.2.2009, (2009b)

16. Ustawa z dnia 6 stycznia 2005 r. o mniejszościach narodowych i etnicznych oraz o języku regionalnym, Dz.U. 2005 nr 17 poz. 141 (2005)

17. UNESCO, Salamanca Statement and Framework for Action on Special Needs Education, Salamanca 1994, retrieved: http://unesdoc.unesco.org/images/0009/000984/098427eo.pdf (Accessed: 3.05.2017).

18. Rozporządzenie Ministra Edukacji Narodowej z dnia 30 kwietnia 2013 roku w sprawie zasad udzielania i organizacji pomocy psychologiczno-pedagogicznej w publicznych przedszkolach, szkołach i placówkach, Dz.U. 2013, poz. 532 (2013)

19. Ibid.

20. Ośrodek Rozwoju Edukacji, Edukacja mniejszości narodowych i etnicznych oraz społeczności posługujacej się językiem regionalnym $w$ Polsce 2010-2011, Warszawa,11 (2012)

21. Ibid., 10

22. K. Białek, Międzykulturowość w szkole. Poradnik dla nauczycieli i specjalistów (ed.), Ośrodek Rozwoju Edukacji, Warszawa, 48-49 (2015)

23. B. Czernecka, Kształcenie nauczycieli zintegrowanej Europy in: Kształcenie nauczycieli w kontekście integracji europejskie, M. Ochmański (ed.), Wyd. UMCS, Lublin, 38-40 (1997)

24. D. Misiejuk, Dzieci imigrantów i mniejszości narodowych in: Małe dziecko w Polsce: raport o sytuacji edukacji elementarnej, T. Szlendak (ed.), Fundacja Rozwoju Dzieci, Warszawa, 147 (2006)

25. Ibid, 148

26. K. M. Błeszyńska, Dzieci obcokrajowców w polskich placówkach oświatowych perspektywa szkoły, Ośrodek Rozwoju Edukacji, Warszawa, 74-76 (2010)

27. Ibid., 76-79

28. S. Severiens, Developing School Capacity for Diversity, SIRIUS Network, 4 (2014). 